\title{
Albedo reduction caused by black carbon and dust accumulation: a quantitive model applied to the western margin of the Greenland ice sheet
}

\section{T. Goelles ${ }^{1,2}$ and C. E. Bøggild ${ }^{3}$}

${ }^{1}$ The University Centre in Svalbard (UNIS), Longyearbyen, Norway

${ }^{2}$ Norwegian University of Life Sciences (NMBU), Aas, Norway

${ }^{3}$ Arctic Technology Centre, Technical University of Denmark, Kgs. Lyngby, Denmark

Received: 27 January 2015 - Accepted: 11 February 2015 - Published: 26 February 2015

Correspondence to: T. Goelles (thomas.golles@unis.no, thomas.goelles@gmail.com)

Published by Copernicus Publications on behalf of the European Geosciences Union.

Black carbon and dust accumulation

T. Goelles and

C. E. Bøggild

\section{Title Page}

14

4

Back

Full Screen / Esc

Printer-friendly Version

Interactive Discussion 


\section{Abstract}

Ice loss due to surface melt of the Greenland ice sheet has increased in recent years. Surface melt in the ablation zone is controlled by atmospheric temperature and surface albedo. Impurities such as mineral dust and black carbon darken the snow and

5 ice surfaces and therefore reduce the surface albedo which leads to more absorbed solar energy and ultimately amplifying melt. These impurities accumulate on the ice surface both from atmospheric fallout and by melt-out of material which was enclosed in the snowpack or the ice compound. A general impurity accumulation model is developed and applied to calculate the surface albedo evolution at two locations in western Greenland. The model is forced either by regional climate model output or by a parameterisation for temperature and precipitation. Simulations identify mineral dust as the main contributor to impurity mass on ice where the dominating part originates from melt out of englacial dust. Daily reduction of impurities is in the range of one per-mille which leads to a residence time of decades on the ice surface. Therefore the impurities have a prolonged effect on surface melt once they are located on the ice surface. The currently englacially stored mineral dust and black carbon will effect future melt and sea level rise and can be studied with the presented model.

\section{Introduction}

Sea level rise due to melting and calving of ice sheets and glaciers is a major concern in association with climate change and has attracted considerable attention. Ice loss of the Greenland Ice Sheet (GrIS) has increased in recent years (Vaughan et al., 2013) where until 2009 the ice loss due to surface melt accounted for 50\% (Van den Broeke et al., 2009a) and up to $84 \%$ after (Enderlin et al., 2014).

Absorption of shortwave radiation is the largest energy source for ice and snow melt 25 (i.e. Male and Granger, 1981; Cuffey and Paterson, 2010). Surface albedo and incident radiation are controlling the amount of absorbed shortwave radiation, hence surface
Black carbon and dust accumulation

T. Goelles and

C. E. Bøggild

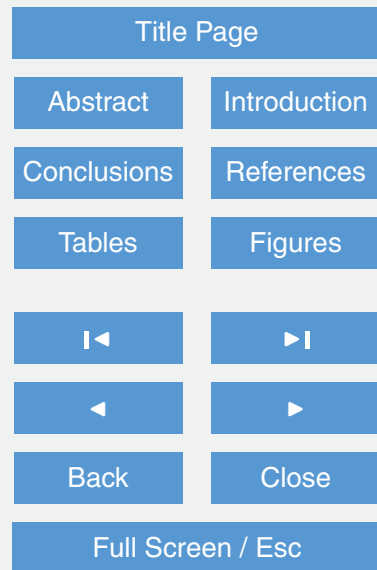

Printer-friendly Version

Interactive Discussion 
albedo has been identified as a major component of the surface mass balance for ice sheets (e.g. van Angelen et al., 2012; Bougamont et al., 2005; Tedesco et al., 2011). Despite the importance of albedo it is rarely included in ice sheet model and if it is then treated as constant in time and space (e.g. Konzelmann and Braithwaite, 1995; Hock 5 and Noetzli, 1997; Robinson et al., 2011, 2010; Bougamont et al., 2005). Sensitivity experiments of the GrIS (Machguth et al., 2013) suggest that the present high mass loss could be $20-30 \%$ higher if the surface albedo would be significantly lower in the future. Currently a downward trend in the surface albedo is observed at the GrIS margin with a decrease by up to $18 \%$ in coastal regions (Box et al., 2012).

10 Impurities such as black carbon (BC), mineral dust (Warren and Wiscombe, 1980) and microbes affect the albedo of snow and ice. Microbes may influence the albedo by aggregating material (Takeuchi et al., 2001) and by producing dark materials (Takeuchi, 2002; Remias et al., 2012). Yet the influence or microbes on surface albedo remains to be quantified (Stibal et al., 2012; Yallop et al., 2012) as its dynamics are currently 15 not well understood. Other impurities are aerosols, which in the context of glaciers, are eolian transported particles which are located on, or inside the snowpack and glacier ice. Only at the very margin surfacing till from the base of the glacier become significant and can locally affect the albedo. Albedo relevant aerosols are $\mathrm{BC}$ originating from natural or man-made forrest fires or incomplete fuel composition as well as mineral dust produced by weathering of the earth surface. Mineral dust (subsequently referred to as just dust) is the main contributor to total impurity mass (e.g. Takeuchi et al., 2014) but $B C$ is much more effective in reducing albedo (Warren and Wiscombe, 1980). Just a few nano-gram of BC have a significant impact on ice and snow albedo. Termination of the little ice age has been reported to be possibly caused by industrial BC (Painter 25 et al., 2013).

Large ice masses act as a reservoir of dust and BC by entraining the particles in the accumulation zone which are later released at the margin after centuries or millennia of transport. These englacial impurities accumulate (e.g. Oerlemans, 1991; Bøggild et al., 1996; Klok and Oerlemans, 2002; Oerlemans et al., 2009) at the ice surface as

Black carbon and dust accumulation

T. Goelles and

C. E. Bøggild

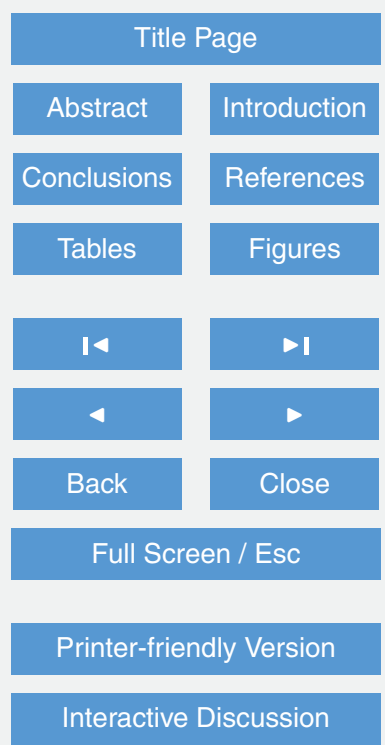


they melt-out and therefore have a long-time effect on surface melt. Between 1850 to 1951 North America is probably the main source of BC in central Greenland where current emissions are almost back to pre-industrial levels (McConnell et al., 2007). Nevertheless today the main source is probably Asia (McConnell et al., 2007; Koch 5 and Hansen, 2005) also found to be the main source of dust in the past (Biscaye et al., 1997). Asian BC emissions were rising since 2000 and in particular in China by about $30 \%$ (Lei et al., 2011) to $40 \%$ (Lu et al., 2011).

Together with the high concentrations of dust from glacial times currently stored inside the GrIS this forms a potential major source of uncertainty to future sea level rise. 10 Model projections of future melt of glaciers and ice sheets might be underestimated without accounting for the influence of impurities on ice albedo.

Sophisticated snow albedo models like SNICAR (Flanner and Zender, 2006) have existed for some time. While these models are computationally to demanding to include in large scale models they give important insight to efficient parameterisations (Pirazz-

ini, 2009). Global circulation models use different snow albedo models with different levels of complexity and some may include simple parameterisation of impurities (Dolan et al., 2014). However, a physical based model of ice albedo which includes the accumulation of impurities is still missing.

Our goal in this paper is twofold. Firstly, development of a computationally efficient 20 albedo model which takes outcropping and accumulation of impurities on the ice surface into account. Secondly, we examined the relative contribution of outcropping dust and $\mathrm{BC}$ to the total impurity mass and investigate its residence time on the surface at two locations on the western margin of Greenland based on local meteorological data.
TCD

$9,1345-1381,2015$

Black carbon and dust accumulation

T. Goelles and

C. E. Bøggild

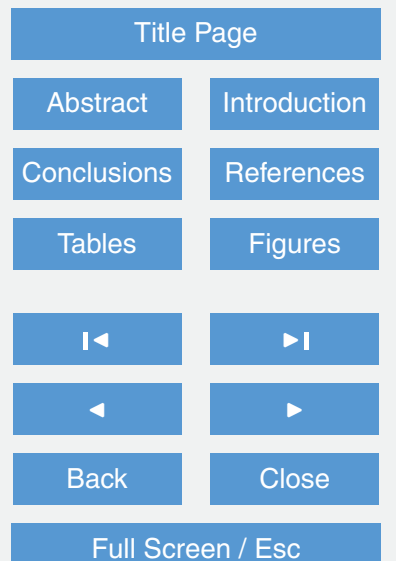

Full Screen / Esc

Printer-friendly Version

Interactive Discussion 


\section{Model description}

\subsection{Impurity accumulation}

The surface albedo of an ice sheet (Fig. 1) is influenced by several processes. In principle there are three factors: optical properties of the surface (albedo), angle of incidence

5 of downward radiation and proportions of direct to diffuse radiation (Cuffey and Paterson, 2010).

The surface property of an ice sheet is primarily effected by surface type (snow or ice) and secondarily by the optical surface properties. This is because the difference between snow and ice albedo is normally greater than between dry and wet snow.

10 The optical properties of snow and ice are determined by impurities and the specific surface area of the material. The specific surface area of snow is determined by snow metamorphism and of ice by enclosed air, cracks and the magnitude of the ablation crust (Müller and Keeler, 1969). The magnitude of diffuse scatter below the surface and therefore the albedo is effected by this specific surface area.

Impurities such as BC, mineral dust and microbes have different origins and accumulating on the ice and snow surface. There are four different sources of impurities at the ice surface in the ablation zone (Fig. 2):

- atmosphere: $k_{1}$ by dry or wet deposition,

- tundra: $k_{||}$by regionally transported material from the surrounding tundra,

- flow: $k_{\text {III }}$ by transport from the accumulation zone to the ablation zone where impurities melt-out,

- local: $k_{\mathrm{IV}}$ by local biological production of dark material on the ice or snow surface.

For model purpose the accumulation has to be treated separately for each impurity species with different considerations for snow and ice. Since the microbiological interaction is not yet well understood we limit ourself to $\mathrm{BC}(n=1)$ and dust $(n=2)$ only

Black carbon and dust accumulation

T. Goelles and

C. E. Bøggild

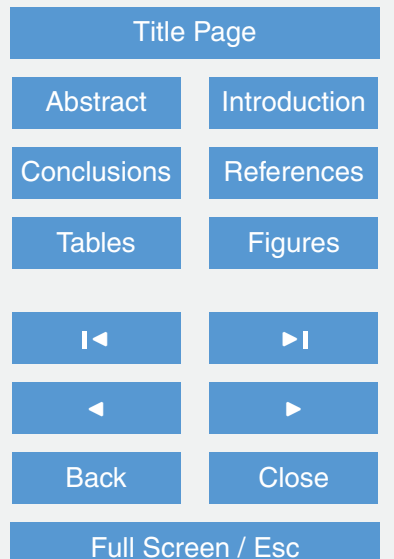

Full Screen / Esc

Printer-friendly Version

Interactive Discussion 
in this study. Nevertheless the equations can be applied for other species, including microbes. We treat the impurities $\iota$ as a mass per area $\left(\mathrm{ngm}^{-2}\right)$. If snow melts then all the impurities are deposited on the ice surface and all the sources contribute directly to the amount on the ice surface. On the other hand if snow covers the ice surface all the 5 sources contribute to the amount in the snowpack and the impurities amount on the ice surface remains constant. Hence the impurity amount located on top of the ice is preserved from one melt season to the next with the additional influx of material from the melted winter snowpack. The total amount is balanced by reduction $\left(r_{\text {ice }, n}(t)\right)$ from the ice surface due to meltwater removal and we assume no loss of impurities up into 10 the snowpack. Moreover, resuspension of formerly deposited aerosols is not likely due to the fact that the surface is either wet or refrozen with the impurity entrained in the frozen ice. We also assume that once aerosol is in the snowpack it is not resuspended again.

Impurity accumulation inside the snowpack (Eq. 1) and on the ice surface (Eq. 2) are 15 described in general by:

$$
\begin{aligned}
& \frac{\mathrm{d} \iota_{\text {snow }}, n}{\mathrm{~d} t}= \begin{cases}k_{\mathrm{l}, n}(t)+k_{\mathrm{II}, n}(t)+k_{\mathrm{IV}, n}(t) & d>0 \\
0 & d=0\end{cases} \\
& \frac{\mathrm{d} \iota_{\mathrm{ice}}, n}{\mathrm{~d} t}= \begin{cases}0 & d>0 \\
k_{\mathrm{I}, n}(t)+k_{\mathrm{II}, n}(t)+k_{\mathrm{III}, n}(t)+ & \\
+k_{\mathrm{IV}, n}(t)-r_{\mathrm{ice}, n}(t) & d=0\end{cases}
\end{aligned}
$$

The in situ production term $k_{\mathrm{IV}, n}(t)$ is only relevant for microbiological activity and is zero otherwise.

20 When ice is melting the impurities transported with the ice from the accumulation zone resurface as they melt out and therefore contribute tot the impurity mass at the ice surface. This is described by the term $k_{\mathrm{III}, n}(t)$ in Eq. (2). We assume that superimposed ice $\left(h_{\mathrm{s} \text {,ice }}\right)$ does not contain any impurities since impurities will not be transported downward with melt water during snow melt, but instead accumulate on the

Black carbon and dust accumulation

T. Goelles and C. E. Bøggild

Title Page

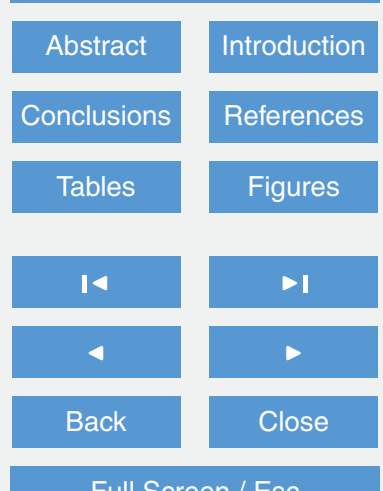

Full Screen / Esc

Printer-friendly Version

Interactive Discussion 
snow surface. Otherwise the source of impurities depends on the englacial impurity concentration nearest to the ice surface, the amount of melt and ice density:

$k_{\text {III }, n}(t)= \begin{cases}{\left[\iota_{n, \text { englacial }}\right] \Delta h_{\text {ice }} \Delta t_{b}^{-1} \rho_{\text {ice }}} & h_{\text {s,ice }}=0 \\ 0 & h_{\text {s,ice }}>0\end{cases}$

For a sufficient short time steps in Eq. (3) $\left(\Delta t_{b}\right)$ ice melt $\Delta h_{\text {ice }}$ is small enough that 5 the englacial aerosol concentration $\left(\left[\iota_{n, \text { englacial }}\right]\right)$ can be treaded as constant. In this study we prescribe the englacial $\left[l_{n \text {,englacial }}\right]$ concentration with values from shallow ice cores.

\subsection{Surface mass balance}

It is necessary to compute ice melt and snow thickness $(d)$ for the accumulation equa10 tions and later also for the resulting surface albedo. The daily change of snow pack height $d$ and ice thickness $h_{\mathrm{i}}$ for the melt-out of englacial impurities with Eqs. (4) and (5) (Robinson, 2011) reads:

$\frac{\mathrm{d}}{\mathrm{d} t_{b}} d=P_{\text {solid }}-M_{\mathrm{s}}, d \in\left(0, d_{\max }\right)$

$\frac{\mathrm{d}}{\mathrm{d} t_{b}} h_{i}= \begin{cases}M_{\mathrm{s}} r_{\mathrm{f}} & d>0 \\ \min \left(P_{\text {solid }}-M_{\mathrm{s}}, 0\right) & d=0\end{cases}$

15 where $P_{\text {solid }}$ is the solid precipitation and $M_{\mathrm{s}}$ the potential melt rate which will be described in the next section in more detail.

If the snow depth exceeds $d_{\max }=5 \mathrm{~m}$ (consistent with Robinson et al., 2010; Fitzgerald et al., 2012) the excess amount is added to the ice thickness and the snow thickness is reset to $5 \mathrm{~m}$.

20 The amount of solid precipitation rate $P_{\text {solid }}$ in Eq. (5) depends on a temperature dependant fraction $f(T)$ and the total amount of precipitation $P$ :

$P_{\text {solid }}=P \cdot f(T)$

Black carbon and

dust accumulation

T. Goelles and

C. E. Bøggild

Title Page

Abstract

Introduction

Conclusions

References

Tables

Figures

14

DI

4

$>$

Back

Close

Full Screen / Esc

Printer-friendly Version

Interactive Discussion

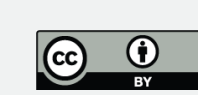


The surface temperature depending fraction $f(T)$ is empirically based on data of Greenland (Bales et al., 2009; Calanca et al., 2000) and states that below a minimum temperature $T_{\min }\left(-7^{\circ} \mathrm{C}\right)$ all precipitation is snow and above a maximum temperature $\left(+7^{\circ} \mathrm{C}\right)$ rain:

$$
5 f(T)= \begin{cases}1 & T<T_{\min } \\ 0 & T>T_{\max } \\ \cos \left(\frac{T-T_{\min }}{T_{\max }-T_{\min }}\right)\left(\frac{\pi}{2}\right) & T_{\min }<T<T_{\max }\end{cases}
$$

Refreezing within a snowpack is a function of the snow depth and the surface temperature $T$ :

$$
r f= \begin{cases}0 & d=0 \\ r_{\max } f(T) & 0<d \leq 1 \\ r_{\max }+\left[\left(1-r_{\max }\right)(d-1)\right] & 1<d \leq 2 \\ 1 & d>2\end{cases}
$$

In the absence of snow the refreezing fraction is 0 . Between 0 and $1 \mathrm{~m}$ w.e. the 10 refreezing fraction is following the definition in Janssens and Huybrechts (2000) and also depending on $f(T)$. Where $r_{\max }$ is the fraction of melt precipitation that has to that has to refreeze before runoff can occur (Fitzgerald et al., 2012).

\subsection{Melt}

We use a simplified energy-balance model based on Oerlemans (2001) and recently

$M_{\mathrm{s}}=\frac{1}{\rho_{\mathrm{w}} L_{\mathrm{m}}}\left[\tau_{a}\left(1-\alpha_{\mathrm{s}}\right) S_{\mathrm{TOA}}+c+\lambda T\right]$

Black carbon and dust accumulation

T. Goelles and

C. E. Bøggild

\section{Title Page}

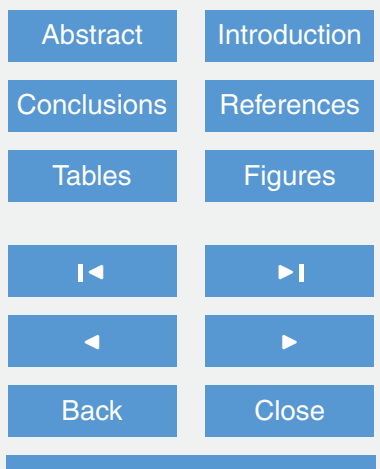

Full Screen / Esc

Printer-friendly Version

Interactive Discussion 
Where $\rho_{\mathrm{w}}$ is the density of water, $L_{\mathrm{m}}$ is the latent heat of melting, $\tau_{a}$ is the transmissivity, $S_{\text {TOA }}$ the insolation on top of the atmosphere, $c$ and $\lambda$ are empirical parameters for short-wave radiation and sensible heat flux and long-wave radiation respectively and $T$ is the surface air temperature. Equation (9) requires only the information of the 5 insolation on top of the atmosphere which can be calculated for any time by simple equations (Liou, 2002). The transmissivity $\tau_{a}$ is based on summer (April-September) radiation data over Greenland and is a linear fit with elevation $h$ in meters (Robinson et al., 2010):

$\tau_{a}=0.46+0.00006 h$

10 The only variable which remains to be described in Eq. (9) is the surface albedo.

\subsection{Surface albedo}

\subsubsection{General albedo paramterisation}

In the absence of snow the surface albedo in Eq. (9) is identical to the ice albedo (see also Fig. 1). From bare ice to a critical snow depth $d_{\text {crit }}$ the surface albedo fades linearly 15 to the snow albedo:

$\alpha_{\mathrm{s}}= \begin{cases}\alpha_{\text {ice }} & d=0 \\ \alpha_{\text {ice }}+\frac{d}{d_{\text {crit }}}\left(\alpha_{\text {snow }}-\alpha_{\text {ice }}\right) & 0<d<d_{\text {crit }} \\ \alpha_{\text {snow }} & d \geq d_{\text {crit }}\end{cases}$

Even with a few centimetres of snow bare ice can be exposed due to meter scale surface undulations of the glacier ice surface and the effect of wind drift.

Equation (11) is a more generalised version of the one used in Robinson et al. (2010, 2011) which uses the parameterisation of Van den Berg et al. (2008). This parameterisation allows the snow albedo to be lower than the ice albedo.

\section{TCD}

$9,1345-1381,2015$

Black carbon and dust accumulation

T. Goelles and

C. E. Bøggild

Title Page

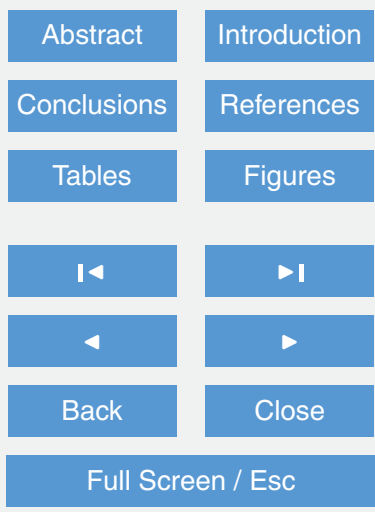

Printer-friendly Version

Interactive Discussion 
The basic method for snow and ice albedo are the same where the albedo is composed of the base albedo and the sum of albedo reductions due to impurities and the influence of the solar zenith angle $\mathrm{d} \alpha_{\theta_{z}}$ :

$\alpha_{\text {ice|snow }}=\alpha_{\text {base }}+\sum_{1}^{n} \mathrm{~d} \alpha_{\iota, \mathrm{n}}+\mathrm{d} \alpha_{\theta_{z}}$

The influence of clouds on albedo is already included in the melt scheme and optimised for GrIS (Robinson et al., 2010) via Eq. (10). The albedo change due to sun zenith angle is also parameterised with the scheme of Gardner and Sharp (2010). At high zenith angles close to solstice at Kangerlussuaq the maximum albedo increase with high impurity loadings is below 0.04 . Therefore we neglect the influence of solar

\subsubsection{Ice albedo}

The base albedo of ice is computed via the specific surface area $\hat{S}$ with Eq. (13) (Gardner and Sharp, 2010):

$\alpha_{\text {base }}=1.48-\hat{S}^{-0.07}$

15 The albedo reduction due to $\mathrm{BC}$ is calculated with the parameterisation in Eq. (14) (Gardner and Sharp, 2010). Dust is included by adding a BC equivalent mass to the BC amount, as dust is about 1/200 (Gardner and Sharp, 2010) less effective per mass:

$\mathrm{d} \alpha_{\iota, \mathrm{n}}=\max \left(0.04-\alpha_{\text {base }}, \frac{-\left[\iota_{\mathrm{eff}, n}\right]^{0.55}}{0.16+0.6 \hat{S}^{0.5}+1.8\left[\iota_{\mathrm{eff}, n}\right]^{0.6} \hat{S}^{-0.25}}\right)$

20 Where $\iota_{\text {eff,BC }}$ is the effective aerosol concentration in ppm described as:

$\left[\iota_{\text {eff }, n}\right]=\left[\iota_{n, \text { englacial }}\right]+\left[\iota_{\text {ice }, n}\right] \cdot \mathcal{F}_{\text {ice }, n}$

Black carbon and dust accumulation

T. Goelles and

C. E. Bøggild

Title Page

Abstract

Introduction

Conclusions

References

Tables

Figures

14

$\rightarrow 1$

4

Back

$\triangleright$

Close

Full Screen / Esc

Printer-friendly Version

Interactive Discussion 
The active fraction $\mathcal{F}_{\text {ice, } n}$ describes the fact that not all impurities are influencing the albedo. Measurements of cryoconite holes at the GrlS margin (Bøggild et al., 2010) has shown that a considerable mass of impurities, in the order of kilograms per square meter, is located inside the holes. The holes are vertical but the incident solar radiation 5 is mostly non zenith reducing the impact of radiation on impurity melt in the bottom of the hole to nearly zero.

Since Eq. (14) requires a concentration in ppm and the accumulation model handles the total amount in $\mathrm{ng} \mathrm{m}^{-2}$ a conversion is necessary:

$\left[\iota_{n}\right]=\frac{\iota_{n}}{\rho d_{\mathrm{eff}}} 10^{6}$

10 Where the impurity concentration is in ppm when the impurity amount is in $\mathrm{ng} \mathrm{m}^{-2}$ and the effective depth $d_{\text {eff }}$ is in meters and density is in $\mathrm{kgm}^{-3}$. The effective depth and the active fraction on ice are not well constrained and both have the same effect on the results. They both describe how effective the total amount of aerosol is in reducing the albedo. This effective depth is related on the absorption length in ice which is depending on wavelength and impurities. We set the effective depth to $5 \mathrm{~m}$ which corresponds to an extinction coefficient of about $1 \mathrm{~m}^{-1}$ which is in the range of totally clear and white ice (Male and Gray, 1981) and leave the active fraction as a free parameter.

\subsubsection{Snow albedo}

In this study we focus manly on ice albedo and therefore left the snow albedo is defined by differentiating between wet and dry snow as in Robinson et al. (2010) although the model includes also snow albedo reduction due to $B C$ and dust. This does not limit the main conclusions of this study as accumulation of $B C$ and dust inside the snowpack is included. On a side note, our snowpack model has no layers but impurities such as BC (Doherty et al., 2013) are usually located close to the surface which can be

\section{TCD}

$9,1345-1381,2015$

Black carbon and

dust accumulation

T. Goelles and

C. E. Bøggild

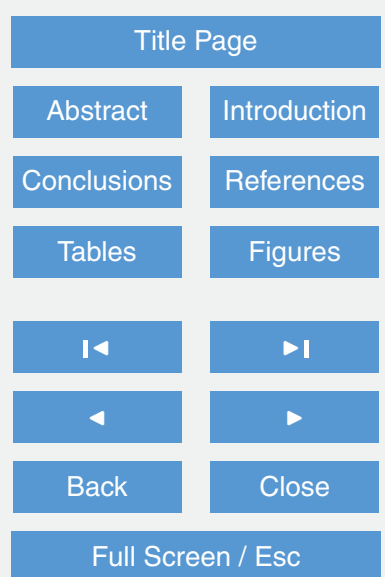

Printer-friendly Version

Interactive Discussion 


\subsection{Model setup}

Figure 3 shows the flow chart of the model for one time-step. First the climate parameters are updated and the snow-depth is calculated with the melt amount from the previous time-step. Then the aerosol accumulation of $\mathrm{BC}$ and dust in snow and on the 5 ice surface is calculated which are then passed to the snow and ice albedo modules. Where different methods of calculating the albedo from aerosols are implemented and in this study the parameterisation from Gardner and Sharp (2010) is used. Then the resulting surface type and albedo is derived and used as input to the potential melt scheme, which affect the refreezing amount and ultimately in the surface mass bal10 ance.

\section{The model applied to the western margin of Greenland}

\section{$3.1 \quad$ K-transect}

The model is tested and forced with data from the K-transect (also known as Søndre Strømfjord transect) on the western Greenland margin near Kangerlussuaq airport (Fig. 4) at a latitude of $67^{\circ} \mathrm{N}$. The transect is about $140 \mathrm{~km}$ long and reach from an elevation of 460 up to $1850 \mathrm{~m}$ i.e. above the equilibrium line which is located around $1500 \mathrm{~m}$ (Van de Wal et al., 2005) and KAN_U and S10 are located in the accumulation zone. The Institute for Marine and Atmospheric Research in Utrecht (IMAU) and later the Geological Survey of Denmark and Greenland (GEUS) (Van As et al., 2011) each operate three automatic weather stations (AWS). Even before IMAU installed the first AWS (S5, S6, S9) for continuous measurements since 2003 (Van den Broeke et al., 2009b) surface mass balance studies have been done (Van de Wal et al., 2012) since the beginning of the 1990s. A dark region persists below the equilibrium line (Van de Wal, 1992 as cited in Wientjes and Oerlemans, 2010) in each year. At $67^{\circ} \mathrm{N}$ the dark region is about $30 \mathrm{~km}$ wide and starts at approximately $30 \mathrm{~km}$ away from the
Black carbon and dust accumulation

T. Goelles and

C. E. Bøggild

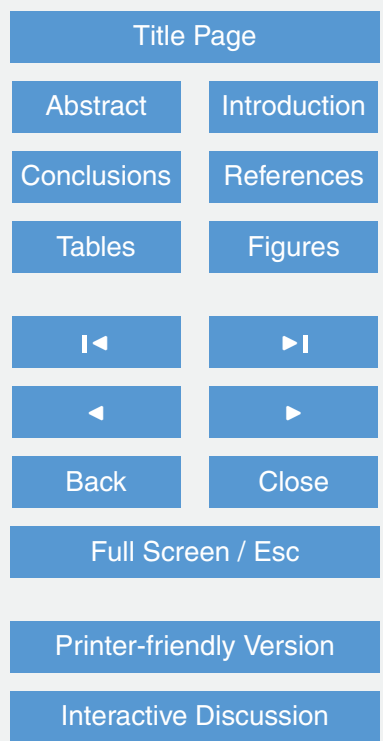


margin (Wientjes and Oerlemans, 2010). Perviously meltwater was believed to be the cause (Zuo and Oerlemans, 1996) but now is attributed to dust (Wientjes and Oerlemans, 2010) and carbonaceous particles (Wientjes et al., 2012).

Reference surface albedo is calculated from daily mean data from the GEUS stations 5 and hourly data for IMAU stations, where only data with a solar angle above $15^{\circ}$ are used. This was found to be in agreement with the data where as $10^{\circ}$ was used (Van As et al., 2005) before.

\subsection{Experimental design and parameters}

In order to compute the impurity and albedo evolution at the K-Transect the model 10 parameters needs to be adjusted specifically for this particular environment. Some standard physical parameters common for all locations are listed in Table 1.

The model is applied to stations KAN_M and S5 because they both have the full cycle with dry snow, wet snow and exposed ice over the annual cycle. Station KAN_M is situated in the dark zone at $1280 \mathrm{~m}$ a.s.I and S5 is close to the margin at $460 \mathrm{~m}$ a.s.I 5 with more reflectant ice but higher surface ablation due to higher temperatures. Station S5 has the longer record and was chosen over KAN_B and KAN_L. Station S6 has only complete data for the period 2005-2007 and was therefore left out.

Adjustable free parameters are: dry snow albedo, wet snow albedo, critical snow depth, the active fraction of BC and dust on ice, the specific surface area of ice and reduction fraction on ice. Which makes in total six free parameters.

The best parameter combination was derived by a Monte-Carlo method by taking the combination with the lowest value of $\mathcal{S}$ after a spin-up:

$\mathcal{S}=\sum_{01.04}^{30.09}\left|\alpha_{\mathrm{mod}}-\alpha_{\mathrm{dat}}\right|$
TCD

$9,1345-1381,2015$

Black carbon and

dust accumulation

T. Goelles and

C. E. Bøggild

Title Page

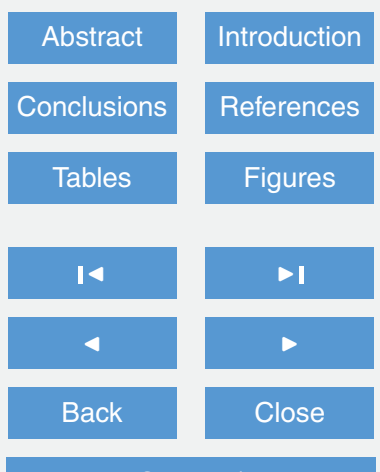

Full Screen / Esc

Printer-friendly Version

Interactive Discussion 
Parameter ranges taken into account can be seen in Fig. 6c. The active fraction of dust and BC was further optimised manually to improve the fit between model and observation after the Monte-Carlo search.

We use 100 years for the spin-up in order to guarantee that the model reaches an 5 equilibrium with all parameter combinations. This long spin-up time also allowed to start with no snow and without aerosols on snow and ice. In practice with realistic parameter combinations the equilibrium is reached much earlier and how long it takes is primarily controlled by the reduction fraction.

The englacial BC value from KAN_M is taken from an ice core (Wientjes et al., 2012) 10 at location S8 ( $7.25 \mathrm{~km}$ south-west) and is $4 \mathrm{ngg}^{-1}$. For S5 the value is set to $1 \mathrm{ng} \mathrm{g}^{-1}$ based on the closely located $\mathrm{S} 1$ core.

For dust the englacial value at KAN_M is set to 2000 and $100 \mathrm{ng} \mathrm{g}^{-1}$ at S5 as it is located in a cleaner region. These values are based on assumptions from the NGRIP core (Ruth, 2007) and the effect of these assumptions is discussed later (Sect. 5.2).

The atmospheric input rate ( $\mathrm{kll}$ ) of $\mathrm{BC}$ at both stations is $20 \mathrm{ng} \mathrm{m}^{-2} \mathrm{a}^{-1}$ (Bauer et al., 2013) which also corresponds to the maximum value found in a snow sample close to Dye-2 (Doherty et al., 2013). For dust a value of $1 \mathrm{~g} \mathrm{~m}^{-2} \mathrm{a}^{-1}$ taken everywhere from the mean value of Mahowald et al. (1999). The melt-out rate of aerosols is calculated (kIII) and all the other contributors from tundra and local production are assumed to be zero. This might lead for an underestimation of the dust as a significant amount could be transported from the surrounding tundra to the ice. Nevertheless the tundra input might be neglect-able as the dark region is $30 \mathrm{~km}$ away from the margin which indicates the insignificance of direct input from the tundra (Wientjes and Oerlemans, 2010).

The experiments are carried out once with temperature from AWS data and daily precipitation from MAR (Tedesco et al., 2014) model output and once with the parameterisation of those, as presented in the next section.

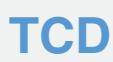

9, 1345-1381, 2015

Black carbon and dust accumulation

T. Goelles and

C. E. Bøggild

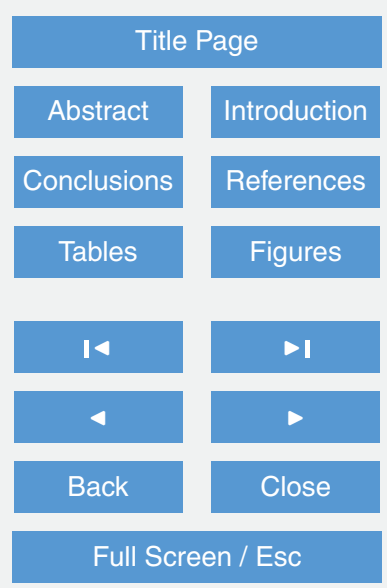

Printer-friendly Version

Interactive Discussion 


\subsection{Temperature and precipitation parameterisation}

As the model should be applicable for studies with long timescale a parameterisation of temperature and precipitation is required. The temperature in the K-transect has a high variability in the cold months (Figs. 5 and 7a) and is stably during the warmer summer 5 season due to the fact that ice is cooling air temperatures during melt. Therefore we choose to parameterise the near surface air temperature not with a sinusoidal shape otherwise used (e.g. Reeh, 1991) but via a trapezoid shape:

$T= \begin{cases}T_{+} & t_{\mathrm{O}, \mathrm{start}} \leq t \leq t_{\mathrm{O}, \mathrm{end}} \\ t \varsigma-t_{\mathrm{O}, \text { start }} \varsigma+T_{+} & t<t_{\mathrm{O}, \text { start }} \\ -t_{\mathrm{O}}+t_{\mathrm{O}, \mathrm{end}} \zeta+T_{+} & t>t_{\mathrm{O}, \mathrm{end}}\end{cases}$

Where $T_{+}$is the mean of all temperatures above $0{ }^{\circ} \mathrm{C}$ and $t_{O \text {,start }} t_{O \text {,end }}$ are the days 10 when summer starts and ends. At the K-transect we assumed a start of summer of first of May and ends at first of September. The non-summer temperatures are defined by the slope $\varsigma$. This is a parameterisation of temperature with only two parameters, namely the slope and the mean positive temperature $T_{+}$.

The precipitation rate is parameterised with a sinusoidal shape in Eq. (19) where ${ }_{15} \Delta P_{\text {jul }}$ is the precipitation rate offset in July $\bar{P}$ is the mean precipitation rate and $\mathcal{A}$ are seconds per year:

$P=\bar{P}+\Delta P_{\text {jul }} \sin \left(\frac{2 t \pi}{\mathcal{A}}+1.5 \pi\right)$

\section{Modeling results}

\subsection{KAN_M in 2010}

20 Figure 5 displays detailed results of simulations of the KAN_M station in the dark zone of the K-transect in the year 2010. Details of the settings can be seen in Fig. 6c (green

Black carbon and dust accumulation

T. Goelles and

C. E. Bøggild

Title Page

Abstract Introduction

Conclusions References

Tables Figures

14

4

Back

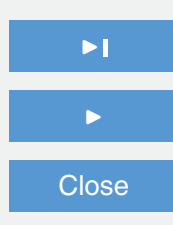

Full Screen / Esc

Printer-friendly Version

Interactive Discussion 
colors). Figure 5 shows both simulations which use weather station temperature and MAR- model precipitation in green and with the temperature and precipitation parameterisation in dotted lines. The temperature parameterisation in panel a is based on all the available data from 2009 until end 2012 by fitting the temperature over the entire 5 period with a mean of $1.39^{\circ} \mathrm{C}$ and a SD of 0.04 . This emphasises the low temperature variability at summer and the good fit of the parameterisation at the melt period. Panel $b$ shows the daily precipitation of the MAR model and the parameterisation. Here we use the mean precipitation over the whole measurement period which results in a similar snow depth time-series (panel e) as with the MAR precipitation. Plots $c$ and $d$ show 10 the BC and dust amount in the snowpack and on the ice surface respectively. Note the different scales for the different species and for snow and ice, respectively. The amount of aerosols in the snowpack is building up over time and is released onto the ice surface as the snow is melting, which coincides with superimposed ice formation. As we assumed no aerosol content in superimposed ice the aerosol content drops as 15 a result of missing influx from ice melt and runoff on the ice surface. Superimposed ice exposure can be seen in panel f. Later in the melt season the aerosol amount on the ice surface rises again as englacial aerosols are released and accumulating until it balances with runoff and reaches its equilibrium level again, which is then preserved under the new snow cover until the next melt season.

The simulated maximum amount of $B C$ on the surface is $0.051 \mathrm{~g} \mathrm{~m}^{-2}$ and of dust is $25.82 \mathrm{~g} \mathrm{~m}^{-2}$. Hence the amount of dust is 502 times larger then black carbon.

The time series of the albedo is shown in panel $\mathrm{g}$, for comparison the MAR computed albedo is plotted as a dashed line. In 2010 the simulated ice albedo reduction due to accumulated impurities was 0.11 from the base ice albedo.

\subsection{Simulations of KAN_M from 2009 until 2013}

Figure 6 presents an overview of different parameter values and model results compared to AWS data. Panel a shows the models with temperature from AWS data and MAR precipitation for each day with four different parameter configurations in panel $\mathrm{c}$.

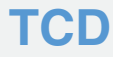

$9,1345-1381,2015$

Black carbon and dust accumulation

T. Goelles and

C. E. Bøggild

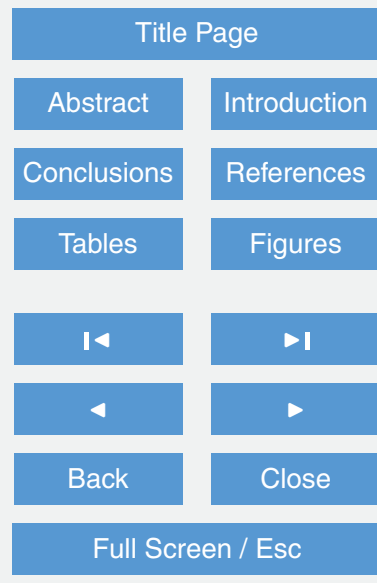

Printer-friendly Version

Interactive Discussion 
Each one is optimised for a different year. Panel b uses the same parameter configurations but this time the temperature and precipitation are parameterized with mean temperatures and precipitations calculated over the whole period.

In the simulations the optimisation of the year 2009 was problematic as the autumn 5 snow cover was building up earlier than normal. Also the parameters set for this year failed to reproduce the low albedo in 2010 but succeeded partly in 2011 and 2012.

\subsection{Stations S5 in 2011}

Figure 7 displays the simulation of station S5 in 2011. Station S5 is located close to the margin at low elevation and therefore experiences more surface melt than KAN_M because of higher temperatures there. The parameter setting is shown in Fig. $6 \mathrm{c}$ and for the temperature parameterisation the data from 2005 until the end of 2012 is used with the positive temperature of $3.60^{\circ} \mathrm{C}$ with a SD of 0.02 .

In panel $d$ the aerosol evolution on the ice surface is shown, with an amount of $B C$ on the ice surface of 0.017 and $1.84 \mathrm{~g} \mathrm{~m}^{-2}$ dust. Comparing it with the equivalent plot of the KAN_M station Fig. $5 \mathrm{~d}$ the different scales have to be taken into account. Although the surface melt is about double here as compared to KAN_M the aerosol amount is less because of the lower englacial content. A small peak in the dust amount of the ice surface can be seen after the dust content of the snowpack has been deposited on ice. This also emphasises the relative magnitude of aerosols deposited from atmosphere as opposed to melted out aerosols. Since the time with (panel f) superimposed ice is much shorter here the time evolution of aerosols does not have the drop at the beginning when ice is exposed.

The high ice albedos at S5 makes it necessary to set the active fraction of BC and dust to zero. Hence the already low amount of aerosols may be mostly trapped in

\section{TCD}

$9,1345-1381,2015$

Black carbon and dust accumulation

T. Goelles and

C. E. Bøggild

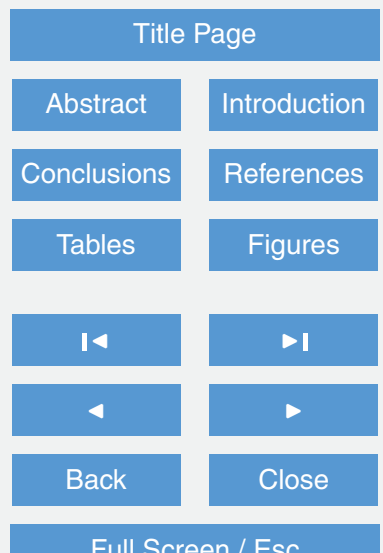

Full Screen / Esc

Printer-friendly Version

Interactive Discussion 


\section{Discussion}

\subsection{General}

In this paper we have introduced a model of dust and black carbon accumulation on the ice surface and its effect on ice albedo of a melting surface. In order to achieve 5 this goal the model depends on several parts (see Fig. 3): temperature, precipitation, melt, snow thickness, aerosol accumulation and snow and ice albedo reduction. Each part has its own limitations and assumptions. Since the overall goal was to be applicable for long time-scales, it is desired to use a limited number of input data types and be computationally efficient. Therefore we parameterised the temperature by a trapezoid shape. This shape follows the measurements reasonable well especially during the melt season when temperature is important for the calculated melt and hence the resulting melt-out of englacial aerosols. Although at station S5 the start of the summer in 2011 and other years was set too early. Therefore it may be better to adjust the start and end of summer individually by location or parameterise it with an elevation dependency for example.

The precipitation was directly parameterised by taking the annual mean as a constant influx over the whole year. This is sufficient to get a comparable snow height evolution as to use the MAR model output because the annual signal are not effected by the high frequency variations. Nevertheless this can not simulate significant summer snowfall which would result in a sudden increase from low ice albedo to high dry snow albedos, as can be seen in the data. This could be realised by coupling the model to a regional climate model which would also allow to account for snow metamorphism via the specific surface area. To study the effect of englacial dust and BC simulations over millennia are required which would make this approach computationally too expensive.

25 Nevertheless to study the long term trend this may not be necessary and the simple parameterisation of temperature and precipitation may be sufficient.

The constant annual cycles of surface albedo in Fig. $6 \mathrm{~b}$ is not just a result of the fixed temperature and precipitation parameterisation, but also because the englacial dust

Black carbon and dust accumulation

T. Goelles and C. E. Bøggild

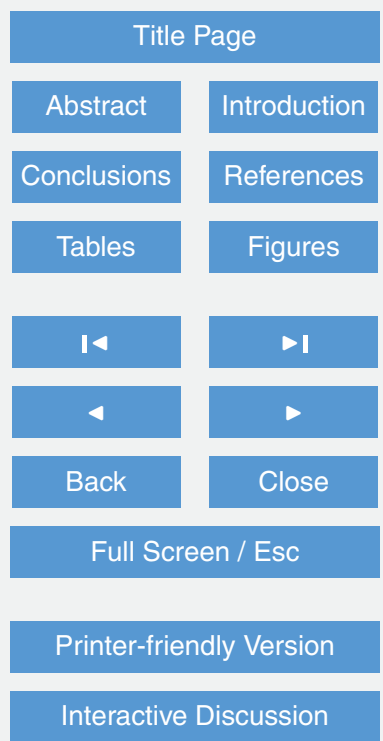


and $\mathrm{BC}$ concentration was set to be constant in this experiments. On longer time-scales these englacial aerosols concentration would vary as the aerosols are transported from the accumulation to the ablation zone. Therefore the ice albedo will vary even when the temperature and precipitation parameterisations maintain a constant annual cycle.

\section{5.2 Amount of accumulated dust and black carbon}

The impurity content on the ice surface is much higher than in the snowpack and in the order of a few grams per square meter which is in the range of observations elsewhere on the Greenland ice sheet (Bøggild et al., 2010; Takeuchi et al., 2014). In our simulations the major contribution to the aerosol content on the ice surface came from outcropping of englacial material. The direct influx of dust and $\mathrm{BC}$ from the atmosphere is comparably insignificant at the ice sheet margin for the total amount of impurities. As just one meter of ice is melting at the margin it releases the accumulated amount of aerosols deposited over years or even decades in the accumulation zone. Closer to the equilibrium line, where melt is less, atmospheric and input from the surrounding tundra may be dominating.

In order to reach the high impurity mass as seen in observations the daily reduction of the accumulated impurities has to be in the order of one per mille. This low value may be a result of slow movement of cryoconite on exposed ice surface as has been measured on Longyearbreen, Svalbard (Irvine-Fynn et al., 2011) and results in a long 20 residence time of impurities once its exposed on the ice surface or in cryoconite holes. It takes more than 56 years in order to reduce from 30 to below one $\mathrm{g} \mathrm{m}^{-2}$ by assuming 60 days with exposed ice and exponential decay with one per mille per day.

In our simulations of station KAN_M in the ablation zone the total amount of impurities was dominated by mineral dust. It contributed 500 times more mass than black carbon. We omitted organic matter which has a low mass-density compared to dust and contributed only about $5 \%$ (Bøggild et al., 2010; Wientjes et al., 2011; Takeuchi et al., 2014) to measurement of total mass. Nevertheless it still may have a significant effect on albedo by being more effective per unit mass then dust. As is BC which is 
100 (Warren and Wiscombe, 1980) to 200 (Gardner and Sharp, 2010) times more absorbent by mass than dust. Since the cores taken by Wientjes et al. (2011) where not analysed for its mineral dust content we choose the englacial dust value of $2000 \mathrm{ng} \mathrm{g}^{-1}$. This is a value of dust concentration from the NGRIP ice core by Ruth (2007) for the late 5 pleistocene. Although the age of the ice by C14 dating and ranges from 3071 BP1950 to modern (Wientjes et al., 2012), and is therefore Holocene. Dust concentration of the Holocene in ice cores is about 100 times lower (Steffensen, 1997). Therefore we also tested the accumulation with just $20 \mathrm{ng} \mathrm{g}^{-1}$ at KAN_M and together with a higher active fraction of 0.6 similar albedo values can be reached although with a much lower total 10 impurity amount of below one $\mathrm{g} \mathrm{m}^{-2}$. Wientjes et al. (2012) explained the higher concentration by a period of enhanced eolian activity in the Holocene. The source of dust of deep cores in the ice sheet interior revealed Asia as the main source of dust (Biscaye et al., 1997; Svensson et al., 2000) although cores from local ice caps (Renland and Hans Tausend) were found to have a more local source (Bory et al., 2003). There might be a "threshold elevation" up to which local dust is contributing and above that elevation large scale transport is dominating and transporting dust from other continents to the GrIS interior.

A detailed study of relative amount of impurities is required to further investigate the concentration to mass of each species. Our simulations give a quantitive estimate of the involved dynamics and the relative importance of outcropping of aerosols. The amount of outcropped material is relative robust, as it is depending on the amount of melt which simulations yielding similar results as observations (Van As et al., 2012) (see Fig. S1 in the Supplement) and the englacial concentration which resulted in a total amount in comparable to observations.

\subsection{Reduced albedo at KAN_M after 2009}

The albedo in summer 2009 was around 0.6 while in 2010 (see Fig. 6a) it dropped to around 0.4 and reached even lower values in the following years. We speculate that

\section{TCD}

$9,1345-1381,2015$

Black carbon and dust accumulation

T. Goelles and

C. E. Bøggild

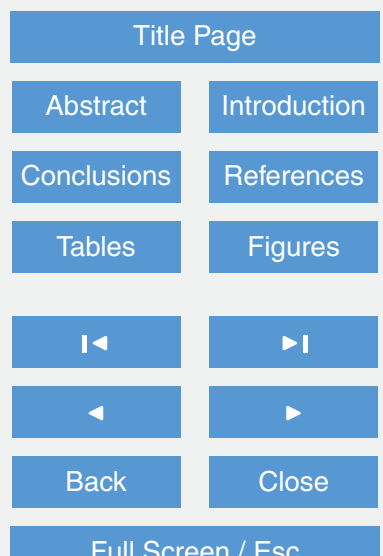

Full Screen / Esc

Printer-friendly Version

Interactive Discussion 
this may have been caused by the high amount of outcropped dust and $\mathrm{BC}$ due to higher temperatures.

The year 2009 was in the range of values between 1974-2010 (Van As et al., 2012) at the Kangerlussuaq station while the average temperature in 2010 was $4.9 \mathrm{~K}$ 5 above average. At KAN_M station at higher elevation the average temperature in 2010 was $4.4 \mathrm{~K}$ warmer than in 2009 which together with low precipitation resulted in enhanced negative surface mass balance of $-1.93 \mathrm{~m}$ w.e. while in 2009 it was only -0.22 mw.e. (Van de Wal et al., 2012) at the closely located Site 8. In 2011 the temperatures where low again, even lower than in 2009 but the surface mass balance 10 remained low $(-1.89)$ due to the low albedo. This effect might be persisted for the upcoming years if the surface is not cleaned by a local event.

\section{Conclusions}

We developed a computationally efficient surface albedo model which takes the accumulation of black carbon (BC) and mineral dust into account and validated it on 15 the K-Transect in western Greenland. The accumulation model calculates release of englacial material which was found to be the main source of impurity mass of which the main contributor was dust. Our simulations suggest a limited loss of impurities on a daily basis in the range of one per-mille which results in a multi-decadal residence time. This indicates that single extreme dust and $\mathrm{BC}$ deposition events would affect the 20 glacier ice albedo for decades.

Future improvements of the model depend on a detailed understanding of the affect of impurity species on ice albedo since black carbon is to our knowledge entirely studied on snow (Hodson, 2014). The key difference of impurity interaction on ice as opposed to snow are the driving surface processes. In this study we lumped all this process together into one parameter - the active fraction. This is a very powerful parameter determining the total impact of impurities on ice albedo. The surface distribution and interaction with cryoconite holes needs to be better understood since it influences

Black carbon and dust accumulation

T. Goelles and

C. E. Bøggild

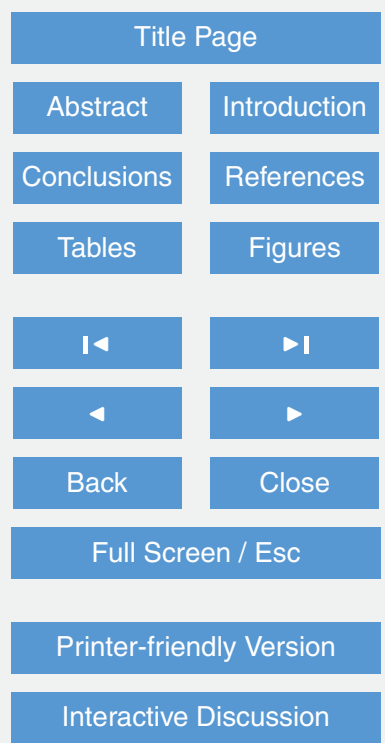

1365 
the residence-time of each species. For that purpose cameras on automatic weather stations could be useful as well as routinely taking surface samples at surface mass balance sites. In addition the microbiological activity and its direct effect on ice albedo has yet to be fully understood and once it is it can easily be incorporated into the

5 model framework. Moreover, the specific surface of the ice i.e. the ablation crust is an important parameter which needs to be quantified.

Together with a transport scheme of englacial aerosols the present albedo model can be used to study the long term effects of natural and anthropogenic aerosols on future melt of glaciers and ice sheets. This model framework could be applied to further 10 investigate the role of black carbon on the termination of the little ice age in the alps for example.

The full benefit of the present model is on long term projections of future sea level rise and can shed light on the way the Greenland ice sheet will be influenced by the dust and $\mathrm{BC}$ currently transported toward the ablation zone inside the ice. As the current 15 source of BC in Greenland is probably Asia the total englacial amount stored in Greenland is still increasing. Fortunately due to modernisation the emissions are expected to decrease until 2030 (Streets, 2007). Nevertheless the full effect of past emissions still remains to come as the particles that melt free at the ice sheet margin, accumulate and impact the melt for long time to come.

\section{The Supplement related to this article is available online at doi:10.5194/tcd-9-1345-2015-supplement.}

Acknowledgements. We would like to thank IMAU and GEUS for providing AWS data of the $\mathrm{K}$-Transect. Ralf Greve who helped in improving the manuscript. This publication is contribution number 60 of the Nordic Centre of Excellence SVALI, "Stability and Variations of Arctic Land Ice", funded by the Nordic Top-level Research Initiative (TRI).

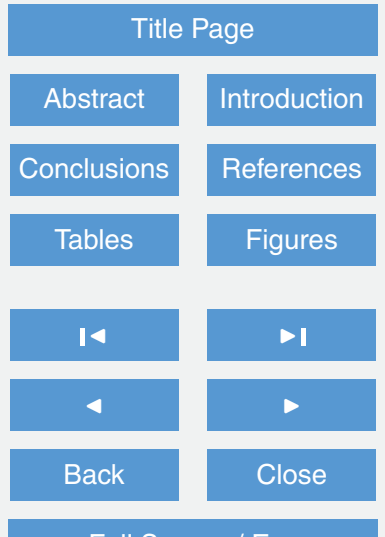

Full Screen / Esc

Printer-friendly Version

Interactive Discussion 


\section{References}

Bales, R. C., Guo, Q., Shen, D., McConnell, J. R., Du, G., Burkhart, J. F., Spikes, V. B., Hanna, E., and Cappelen, J.: Annual accumulation for Greenland updated using ice core data developed during 2000-2006 and analysis of daily coastal meteorological data, J. Geophys. Res., 114, D06116, doi:10.1029/2008JD011208, 2009. 1352

Bauer, S. E., Bausch, A., Nazarenko, L., Tsigaridis, K., Xu, B., Edwards, R., Bisiaux, M., and McConnell, J.: Historical and future black carbon deposition on the three ice caps: ice core measurements and model simulations from 1850 to 2100, J. Geophys. Res.-Atmos., 118, 7948-7961, doi:10.1002/jgrd.50612, 2013. 1358

10 Biscaye, P. E., Grousset, F. E., Revel, M., van der Gaast, S., Zielinski, G. A., Vaars, A., and Kukla, G.: Asian provenance of glacial dust (stage 2) in the Greenland ice sheet project 2 ice core, summit, Greenland, J. Geophys. Res.-Oceans, 102, 26765-26781, doi:10.1029/97JC01249, 1997. 1348, 1364

Bøggild, C. E., Oerter, H., and Tukiainen, T.: Increased ablation of Wisconsin ice in eastern north Greenland: observations and modelling, Ann. Glaciol., 23, 144-148, 1996. 1347

Bøggild, C. E., Brandt, R., Brown, K., and Warren, S. G.: The ablation zone in northeast Greenland: ice types, albedos and impurities, J. Glaciol., 56, 101-113, doi:10.3189/002214310791190776, 2010. 1355, 1363, 1375

Bory, A., Biscaye, P., Piotrowski, A., and Steffensen, J. P.: Regional variability of ice core dust composition and provenance in Greenland, Geochem. Geophy. Geosy., 4, 1107, doi:10.1029/2003GC000627, 2003. 1364

Bougamont, M., Bamber, J. L., and Greuell, W.: A surface mass balance model for the Greenland Ice Sheet, J. Geophys. Res., 110, F04018, doi:10.1029/2005JF000348, 2005. 1347

Box, J. E., Fettweis, X., Stroeve, J. C., Tedesco, M., Hall, D. K., and Steffen, K.: Greenland ice sheet albedo feedback: thermodynamics and atmospheric drivers, The Cryosphere, 6 , 821-839, doi:10.5194/tc-6-821-2012, 2012. 1347

Calanca, P., Gilgen, H., Ekholm, S., and Ohmura, A.: Gridded temperature and accumulation distributions for Greenland for use in cryospheric models, Ann. Glaciol., 31, 118-120, doi:10.3189/172756400781820345, 2000. 1352

30 Cuffey, K. M. and Paterson, W. S. B.: The Physics of Glaciers, 4th Edn., Elsevier Inc., Burlington and Oxford, 2010. 1346, 1349
Black carbon and dust accumulation

T. Goelles and

C. E. Bøggild

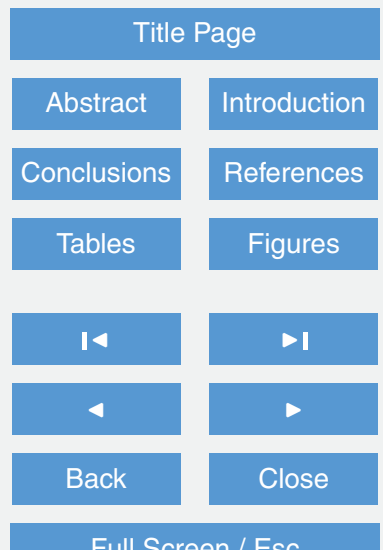

Full Screen / Esc

Printer-friendly Version

Interactive Discussion 
Doherty, S. J., Grenfell, T. C., Forsström, S., Hegg, D. L., Brandt, R., and Warren, S. G.: Observed vertical redistribution of black carbon and other insoluble light-absorbing particles in melting snow, J. Geophys. Res.-Atmos., 118, 5553-5569, doi:10.1002/jgrd.50235, 2013. 1355, 1358

5 Dolan, A. M., Hunter, S. J., Hill, D. J., Haywood, A. M., Koenig, S. J., Otto-Bliesner, B. L., Abe-Ouchi, A., Bragg, F., Chan, W.-L., Chandler, M. A., Contoux, C., Jost, A., Kamae, Y., Lohmann, G., Lunt, D. J., Ramstein, G., Rosenbloom, N. A., Sohl, L., Stepanek, C., Ueda, H., Yan, Q., and Zhang, Z.: Using results from the PlioMIP ensemble to investigate the Greenland Ice Sheet during the warm Pliocene, Clim. Past Discuss., 10, 3483-3535, doi:10.5194/cpd10-3483-2014, 2014. 1348

Enderlin, E. M., Howat, I. M., Jeong, S., Noh, M. J., Angelen, J. H., and Van den Broeke, M. R.: An improved mass budget for the Greenland ice sheet, Geophys. Res. Lett., 41, 866-872, doi:10.1002/(ISSN)1944-8007, 2014. 1346

Fitzgerald, P. W., Bamber, J. L., Ridley, J. K., and Rougier, J. C.: Exploration of parametric uncertainty in a surface mass balance model applied to the Greenland ice sheet, J. Geophys. Res., 117, F01021, doi:10.1029/2011JF002067, 2012. 1351, 1352

Flanner, M. G. and Zender, C. S.: Linking snowpack microphysics and albedo evolution, J. Geophys. Res., 111, D12208, doi:10.1029/2005JD006834, 2006. 1348

Gardner, A. and Sharp, M.: A review of snow and ice albedo and the development of a new physically based broadband albedo parameterization, J. Geophys. Res., 115, F01009, doi:10.1029/2009JF001444, 2010. 1354, 1356, 1364

Hock, R. and Noetzli, C.: Areal melt and discharge modelling of Storglaciären, Sweden, Ann. Glaciol., 24, 211-217, 1997. 1347

Hodson, A. J.: Understanding the dynamics of black carbon and associated contaminants in glacial systems, Wiley Interdisciplinary Reviews: Water, 1, 141-149, doi:10.1002/wat2.1016, 2014. 1365

Irvine-Fynn, T. D. L., Bridge, J. W., and Hodson, A. J.: In situ quantification of supraglacial cryoconite morphodynamics using time-lapse imaging: an example from Svalbard, J. Glaciol., 57, 651-657, doi:10.3189/002214311797409695, 2011. 1363

30 Janssens, I. and Huybrechts, P.: The treatment of meltwater retention in massbalance parameterizations of the Greenland ice sheet, Ann. Glaciol., 31, 133-140, doi:10.3189/172756400781819941, 2000. 1352
TCD

9, 1345-1381, 2015

Black carbon and

dust accumulation

T. Goelles and

C. E. Bøggild

Title Page

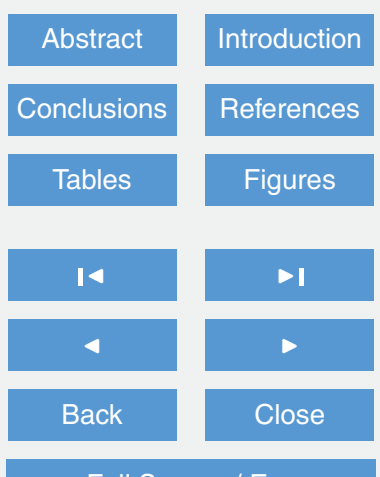

Full Screen / Esc

Printer-friendly Version

Interactive Discussion 
Klok, E. J. and Oerlemans, J.: Model study of the spatial distribution of the energy and mass balance of Morteratschgletscher, Switzerland, J. Glaciol., 48, 505-518, doi:10.3189/172756502781831133, 2002. 1347

Koch, D. and Hansen, J.: Distant origins of Arctic black carbon: a Goddard Institute for Space

$5 \quad$ Studies ModelE experiment, J. Geophys. Res., 110, 4204, 2005. 1348

Konzelmann, T. and Braithwaite, R.: Variations of ablation, albedo and energy balance at the margin of the Greenland ice sheet, Kronprins Christian Land, eastern north Greenland., J. Glaciol., 41, 174-182, 1995. 1347

Lei, Y., Zhang, Q., He, K. B., and Streets, D. G.: Primary anthropogenic aerosol emission trends for China, 1990-2005, Atmos. Chem. Phys., 11, 931-954, doi:10.5194/acp-11-931-2011, 2011. 1348

Liou, K. N.: An Introduction to Atmospheric Radiation, Vol. 84, International Geophysics, Academic Press, San Diego and London, 2 Edn., 2002. 1353

Lu, Z., Zhang, Q., and Streets, D. G.: Sulfur dioxide and primary carbonaceous aerosol emis15 sions in China and India, 1996-2010, Atmos. Chem. Phys., 11, 9839-9864, doi:10.5194/acp11-9839-2011, 2011. 1348

Machguth, H., Rastner, P., Bolch, T., Mölg, N., Sørensen, L. S., Aðalgeirsdóttir, G., van Angelen, J. H., Van den Broeke, M. R., and Fettweis, X.: The future sea-level rise contribution of Greenland's glaciers and ice caps, Environ. Res. Lett., 8, 025005, doi:10.1088/17489326/8/2/025005, 2013. 1347

Mahowald, N. M., Kohfeld, K., Hansson, M. E., Balkanski, Y., Harrison, S. P., Prentice, I. C., Schulz, M., and Rodhe, H.: Dust sources and deposition during the last glacial maximum and current climate: A comparison of model results with paleodata from ice cores and marine sediments, J. Geophys. Res.-Atmos., 104, 15895-15916, doi:10.1029/1999JD900084, 1999. 1358

Male, D. H. and Granger, R. J.: Snow surface energy exchange, Water Resour. Res., 17, 609627, doi:10.1029/WR017i003p00609, 1981. 1346

Male, D. H. and Gray, D. M. (Eds.): Handbook of Snow: Principles, Processes, Management and Use, The Blackburn Press, Caldwell, New Jersey, USA, 1981. 1355

30 McConnell, J., Edwards, R., Kok, G., Flanner, M., Zender, C. S., Saltzman, E., Banta, J., Pasteris, D., Carter, M., and Kahl, J.: 20th-century industrial black carbon emissions altered arctic climate forcing, Science, 317, 1381, doi:10.1126/science.1144856, 2007. 1348

9, 1345-1381, 2015

Black carbon and

dust accumulation

T. Goelles and

C. E. Bøggild

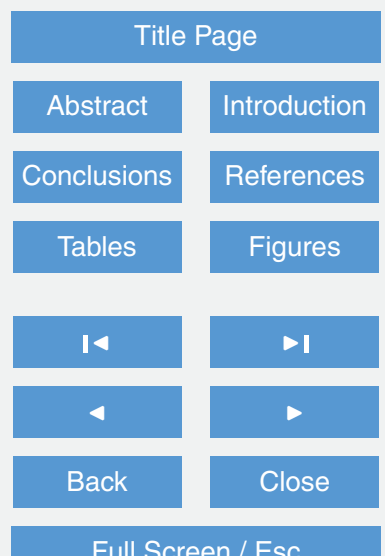

Full Screen / Esc

Printer-friendly Version

Interactive Discussion 
Müller, F. and Keeler, C.: Errors in short-term ablation measurements on melting ice surfaces, J. Glaciol., 8, 91-105, 1969. 1349

Oerlemans, J.: A model for the surface balance of ice masses: Part I: Alpine glaciers, Zeitschrift für Gletscherkunde und Glacialgeologie, 27, 63-83, 1991. 1347

5 Oerlemans, J.: Glaciers and Climate Change, A. A. Balkema Publishers, Lisse; Exton, PA, 2001. 1352

Oerlemans, J., Giesen, R. H., and Van den Broeke, M. R.: Retreating alpine glaciers: increased melt rates due to accumulation of dust (Vadret da Morteratsch, Switzerland), J. Glaciol., 55, 729-736, doi:10.3189/002214309789470969, 2009. 1347

10 Painter, T. H., Flanner, M. G., Kaser, G., Marzeion, B., VanCuren, R. A., and Abdalati, W.: End of the Little Ice Age in the Alps forced by industrial black carbon, P. Natl. Acad. Sci. USA, 110, 15216-15221, doi:10.1073/pnas.1302570110, 2013. 1347

Pirazzini, R.: Challenges in snow and ice albedo parameterizations, Geophysica, 45, 41-62, 2009. 1348

15 Reeh, N.: Parameterization of melt rate and surfaee temperature on the Greenland ice sheet, Polarforschung, 53, 113-128, 1991. 1359

Remias, D., Holzinger, A., Aigner, S., and Luetz, C.: Ecophysiology and ultrastructure of Ancylonema nordenskioldii (Zygnematales, Streptophyta), causing brown ice on glaciers in Svalbard (high arctic), Polar Biol., 35, 899-908, doi:10.1007/s00300-011-1135-6, 2012. 1347

Robinson, A.: Modeling the Greenland Ice Sheet response to climate change in the past and future, Ph. D. thesis, Mathematisch-Naturwissenschaftliche Fakultät der Universität Potsdam, Potsdam, 2011. 1351

Robinson, A., Calov, R., and Ganopolski, A.: An efficient regional energy-moisture balance model for simulation of the Greenland Ice Sheet response to climate change, The Cryosphere, 4, 129-144, doi:10.5194/tc-4-129-2010, 2010. 1347, 1351, 1352, 1353, 1354, 1355

Robinson, A., Calov, R., and Ganopolski, A.: Greenland ice sheet model parameters constrained using simulations of the Eemian Interglacial, Clim. Past, 7, 381-396, doi:10.5194/cp7-381-2011, 2011. 1347, 1352, 1353

30 Ruth, U.: Dust concentration in the NGRIP ice core, doi:10.1594/PANGAEA.587836, Supplement to: Ruth, U., Bigler, M., Röthlisberger, R., Siggaard-Andersen, M.-L., Kipfstuhl, J., GotoAzuma, K., Hansson, M. E., Johnsen, S. J., Lu, H., and Steffensen, J. P.: Ice core evidence

Black carbon and

dust accumulation

T. Goelles and

C. E. Bøggild

Title Page

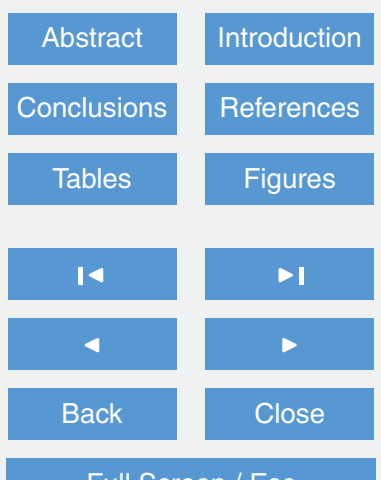

Full Screen / Esc

Printer-friendly Version

Interactive Discussion 
for a very tight link between North Atlantic and east Asian glacial climate, Geophys. Res. Lett., 34, L03706, doi:10.1029/2006GL027876, 2007. 1358, 1364

Steffensen, J. P.: The size distribution of microparticles from selected segments of the Greenland Ice Core Project ice core representing different climatic periods, J. Geophys. Res.-

$5 \quad$ Oceans, 102, 26755-26763, doi:10.1029/97JC01490, 1997. 1364

Stibal, M., Šabacká, M., and Žárský, J.: Biological processes on glacier and ice sheet surfaces, Nat. Geosci., 5, 771-774, doi:10.1038/ngeo1611, 2012. 1347

Streets, D. G.: Dissecting future aerosol emissions: warming tendencies and mitigation opportunities, Climatic Change, 81, 313-330, 2007. 1366

10 Svensson, A., Biscaye, P. E., and Grousset, F. E.: Characterization of late glacial continentaldust in the Greenland Ice Core Project ice core, J. Geophys. Res., 105, 4637-4656, 2000. 1364

Takeuchi, N.: Optical characteristics of cryoconite (surface dust) on glaciers: the relationship between light absorbency and the property of organic matter contained in the cryoconite, Ann. Glaciol., 34, 409-414, doi:10.3189/172756402781817743, 2002. 1347

Takeuchi, N., Kohshima, S., and Seko, K.: Structure, formation, and darkening process of albedo-reducing material (cryoconite) on a Himalayan glacier: a granular algal mat growing on the glacier, Arct. Antarct. Alp. Res., 33, 115-122, doi:10.2307/1552211, 2001. 1347

Takeuchi, N., Nagatsuka, N., Uetake, J., and Shimada, R.: Spatial variations in impurities (cryoconite) on glaciers in northwest Greenland, Bulletin of Glaciological Research, 32, 85-94, doi:10.5331/bgr.32.85, 2014. 1347, 1363

Tedesco, M., Fettweis, X., Van den Broeke, M. R., Van de Wal, R. S. W., Smeets, C. J. P. P., Van de Berg, W. J., Serreze, M. C., and Box, J. E.: The role of albedo and accumulation in the 2010 melting record in Greenland, Environ. Res. Lett., 6, 014005, doi:10.1088/17489326/6/1/014005, 2011. 1347

Tedesco, M., Fettweis, X., Alexander, P., Green, G., and Datta, T.: MAR Greenland Outputs from Outputs 2005-01-01 to 2013-01-01 ver. 3.2, CCNY Digital Archive, online, 2014. 1358

van Angelen, J. H., Lenaerts, J. T. M., Lhermitte, S., Fettweis, X., Kuipers Munneke, P., van den Broeke, M. R., van Meijgaard, E., and Smeets, C. J. P. P.: Sensitivity of Greenland 30 Ice Sheet surface mass balance to surface albedo parameterization: a study with a regional climate model, The Cryosphere, 6, 1175-1186, doi:10.5194/tc-6-1175-2012, 2012. 1347

$9,1345-1381,2015$

Black carbon and

dust accumulation

T. Goelles and

C. E. Bøggild

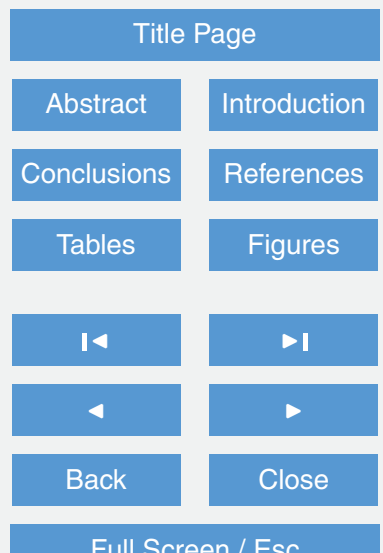

Full Screen / Esc

Printer-friendly Version

Interactive Discussion 
Van As, D., Van den Broeke, M. R., Reijmer, C., and Van de Wal, R. S. W.: The summer surface energy balance of the high Antarctic plateau, Bound.-Lay. Meteorol., 115, 289-317, doi:10.1007/s10546-004-4631-1, 2005. 1357

Van As, D., Fausto, R. S., and Team, P. P.: Programme for Monitoring of the Greenland Ice 5 Sheet (PROMICE): first temperature and ablation records, Geol. Surv. Den. Greenl., 73-76, 2011. 1356

van As, D., Hubbard, A. L., Hasholt, B., Mikkelsen, A. B., van den Broeke, M. R., and Fausto, R. S.: Large surface meltwater discharge from the Kangerlussuaq sector of the Greenland ice sheet during the record-warm year 2010 explained by detailed energy balance observations, The Cryosphere, 6, 199-209, doi:10.5194/tc-6-199-2012, 2012. 1364, 1365

Van de Wal, R. S. W.: Ice and Climate, Ph. D. thesis, Utrecht University, Utrecht, 1992. 1356

Van de Wal, R. S. W., Greuell, W., Van den Broeke, M. R., Reijmer, C. H., and Oerlemans, J.: Surface mass-balance observations and automatic weather station data along a transect near Kangerlussuaq, West Greenland, Ann. Glaciol., 42, 311-316, doi:10.3189/172756405781812529, 2005. 1356

Van de Wal, R. S. W., Boot, W., Smeets, C. J. P. P., Snellen, H., van den Broeke, M. R., and Oerlemans, J.: Twenty-one years of mass balance observations along the K-transect, West Greenland, Earth Syst. Sci. Data, 4, 31-35, doi:10.5194/essd-4-31-2012, 2012. 1356, 1365

Van den Berg, J., Van de Wal, R. S. W., and Oerlemans, J.: A mass balance model for the Eurasian ice sheet for the last 120000 years, Global Planet. Change, 61, 194-208, doi:10.1016/j.gloplacha.2007.08.015, 2008. 1353

Van den Broeke, M. R., Bamber, J., Ettema, J., Rignot, E., Schrama, E., Van de Berg, W. J., van Meijgaard, E., Velicogna, I., and Wouters, B.: Partitioning recent Greenland mass loss, Science, 326, 984-986, doi:10.1126/science.1178176, 2009a. 1346

Van den Broeke, M. R., Smeets, P., and Ettema, J.: Surface layer climate and turbulent exchange in the ablation zone of the west Greenland ice sheet, Int. J. Climatol., 29, 2309-2323, doi:10.1002/joc.1815, 2009b. 1356

Vaughan, D. G., Comiso, J. C., Allison, I., Kaser, G., Kwok, R., Mote, P., Murray, T., Paul, F., so Ren, J., Rignot, E., Solomina, O., Steffen, K., and Zhang, T.: Observations: cryosphere, in: Climate Change 2013: The Physical Science Basis. Contribution of Working Group I to the Fifth Assessment Report of the Intergovernmental Panel on Climate Change, edited by: Stocker, T. F., Qin, D., Plattner, G. K., Tignor, M., Allen, S. K., Boschung, J., Nauels, A.,

\section{Black carbon and \\ dust accumulation \\ T. Goelles and \\ C. E. Bøggild}

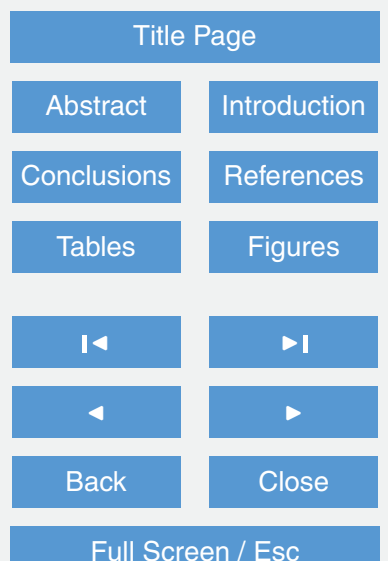

Full Screen / Esc

Printer-friendly Version

Interactive Discussion 
Xia, Y., Bex, V., and Midgley, P. M., Cambridge University Press, Cambridge, UK and New York, NY, USA, 317-382, 2013. 1346

Warren, S. G. and Wiscombe, W. J.: A model for the spectral albedo of snow. II: Snow containing atmospheric aerosols, J. Atmos. Sci., 37, 2734-2745, 1980. 1347, 1364

5 Wientjes, I. G. M. and Oerlemans, J.: An explanation for the dark region in the western melt zone of the Greenland ice sheet, The Cryosphere, 4, 261-268, doi:10.5194/tc-4-261-2010, 2010. 1356, 1357, 1358

Wientjes, I. G. M., Van de Wal, R. S. W., Reichart, G. J., Sluijs, A., and Oerlemans, J.: Dust from the dark region in the western ablation zone of the Greenland ice sheet, The Cryosphere, 5 , 589-601, doi:10.5194/tc-5-589-2011, 2011. 1363, 1364

Wientjes, I. G. M., Van de Wal, R. S. W., Schwikowski, M., Zapf, A., Fahrni, S., and Wacker, L.: Carbonaceous particles reveal that Late Holocene dust causes the dark region in the western ablation zone of the Greenland ice sheet, J. Glaciol., 58, 787-794, doi:10.3189/2012JoG11J165, 2012. 1357, 1358, 1364, 1378

Yallop, M. L., Anesio, A. M., Perkins, R. G., Cook, J., Telling, J., Fagan, D., MacFarlane, J., Stibal, M., Barker, G., Bellas, C., Hodson, A., Tranter, M., Wadham, J., and Roberts, N. W.: Photophysiology and albedo-changing potential of the ice algal community on the surface of the Greenland ice sheet, ISME J., 6, 2302-2313, doi:10.1038/ismej.2012.107, 2012. 1347

Zuo, Z. and Oerlemans, J.: Modelling albedo and specific balance of the Greenland ice sheet: calculations for the Sondre Stromfjord transect, J. Glaciol., 42, 305-317, 1996. 1357

Black carbon and

dust accumulation

T. Goelles and

C. E. Bøggild

Title Page

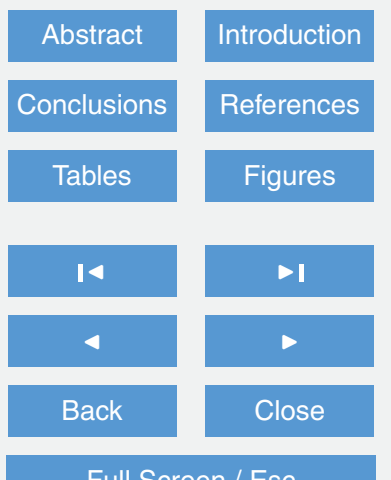

Full Screen / Esc

Printer-friendly Version

Interactive Discussion 
Table 1. Standard physical parameters.

\begin{tabular}{llll}
\hline Symbol & Constant & Value & Unit \\
\hline$\rho_{\text {ice }}$ & Density of ice & 910 & $\mathrm{~kg} \mathrm{~m}^{-3}$ \\
$\rho_{\mathrm{w}}$ & Density of water & 1000 & $\mathrm{~kg} \mathrm{~m}^{-3}$ \\
$\mathcal{A}$ & Seconds per year & 31556926 & - \\
$r_{\max }$ & Refreezing fraction & 0.6 & - \\
$t_{\mathrm{O} \text {,start }}$ & Start of summer & 121 & day of the year \\
$t_{\mathrm{O}, \mathrm{end}}$ & End of summer & 244 & day of the year \\
$\lambda$ & Long-wave radiation coefficient & 10 & $\mathrm{~W} \mathrm{~m}^{-2} \mathrm{~K}^{-1}$ \\
$c$ & Short-wave radiation and sensible heat flux constant & -55 & $\mathrm{~W} \mathrm{~m}^{-2}$ \\
$r_{\max }$ & Refreezing fraction & 0.6 & - \\
$L_{\mathrm{m}}$ & Latent heat for melting of ice & 334000 & $\mathrm{~J} \mathrm{~kg}$ \\
$d_{\text {eff }}$ & Effective depth on ice & 5 & $\mathrm{~m}$ \\
\hline
\end{tabular}

TCD

$9,1345-1381,2015$

Black carbon and dust accumulation

T. Goelles and

C. E. Bøggild

\section{Title Page}

Abstract

Introduction

Conclusions

References

Tables

Figures

14

4

Back

Close

Full Screen / Esc

Printer-friendly Version

Interactive Discussion 


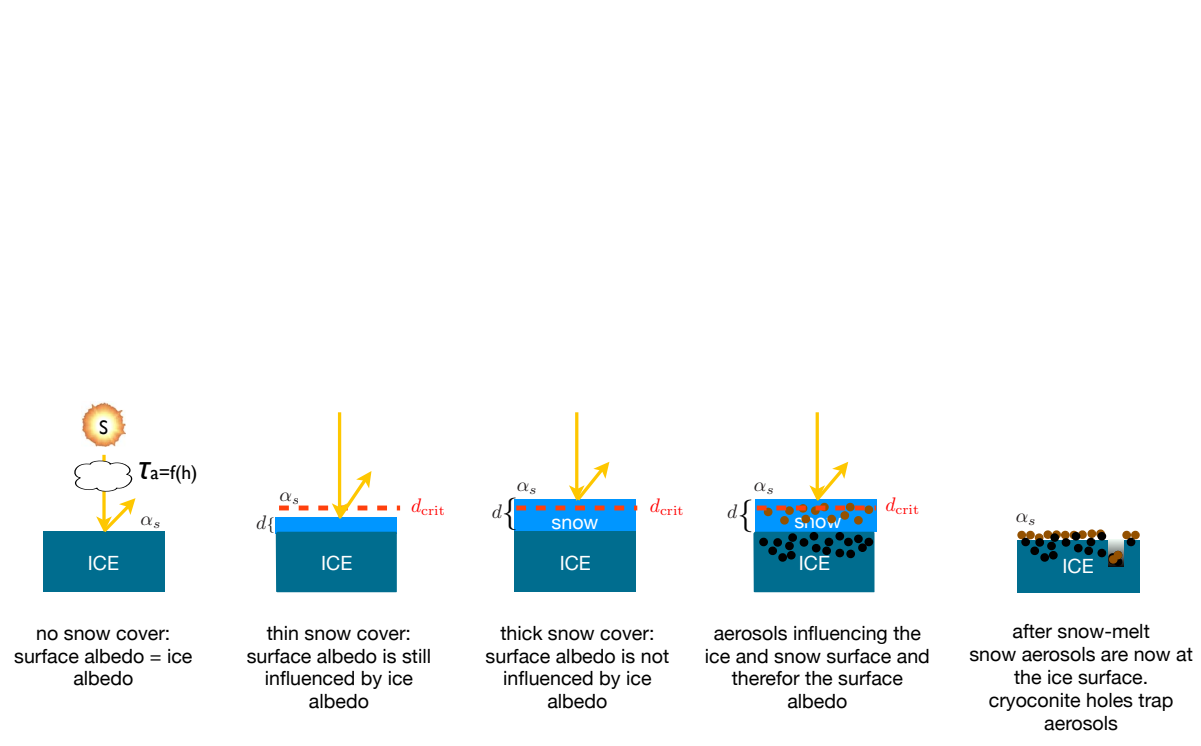

Figure 1. The relationship between ice albedo, snow albedo and aerosol concentration to surface albedo. As ice is exposed to melting, englacial aerosols are released and accumulate on the surface. Some impurities on the ice surface are trapped in cryoconite holes and are therefore not directly contributing to a lower surface albedo (Bøggild et al., 2010). In addition microbiological activity can produce dark material on the snow and ice surface and can enhance the albedo reduction by aggregating the impurities.

Black carbon and dust accumulation

T. Goelles and

C. E. Bøggild

\section{Title Page}

Abstract

Introduction

Conclusions

References

Tables

Figures

14

$>1$

4

Back

$\triangleright$

\section{Full Screen / Esc}

Printer-friendly Version

Interactive Discussion 


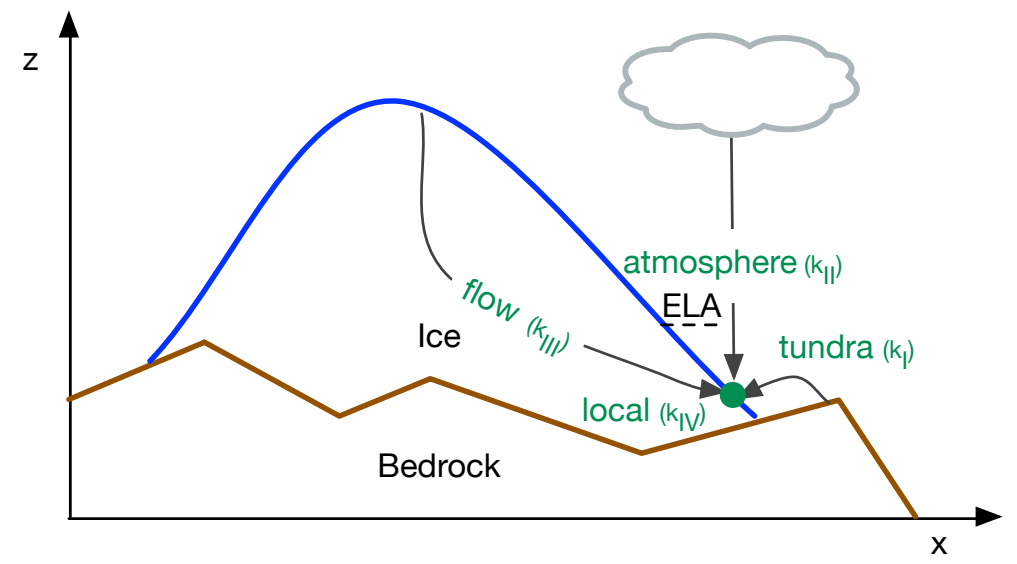

\section{TCD}

9, 1345-1381, 2015

Black carbon and dust accumulation

T. Goelles and

C. E. Bøggild

\section{Title Page}

Abstract

Introduction

Conclusions

References

Tables

Figures

14

4

Figure 2. Cross section through an ice sheet: four different mechanisms of aerosol transport to the ablation zone. ELA stands for equilibrium line altitude.

Back

Close

Full Screen / Esc

Printer-friendly Version

Interactive Discussion

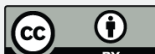




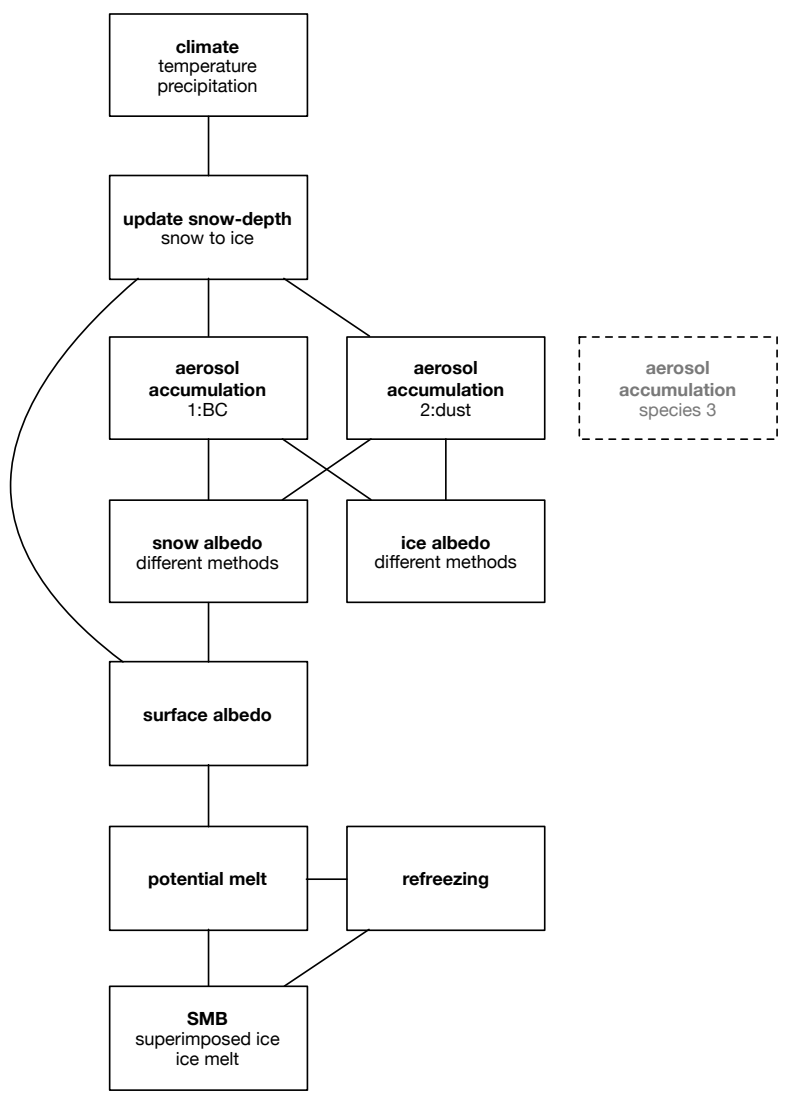

TCD

9, 1345-1381, 2015

Black carbon and dust accumulation

T. Goelles and

C. E. Bøggild

Title Page

Abstract

Introduction

Conclusions

References

Tables

Figures

14

$>1$

4

Back

Close

Full Screen / Esc

Printer-friendly Version

Figure 3. Flow chart of the surface mass balance model inside a loop which is solved for each time-step. Ultimately resulting in an annual SMB which can be used as boundary condition in an ice sheet model.

Interactive Discussion 


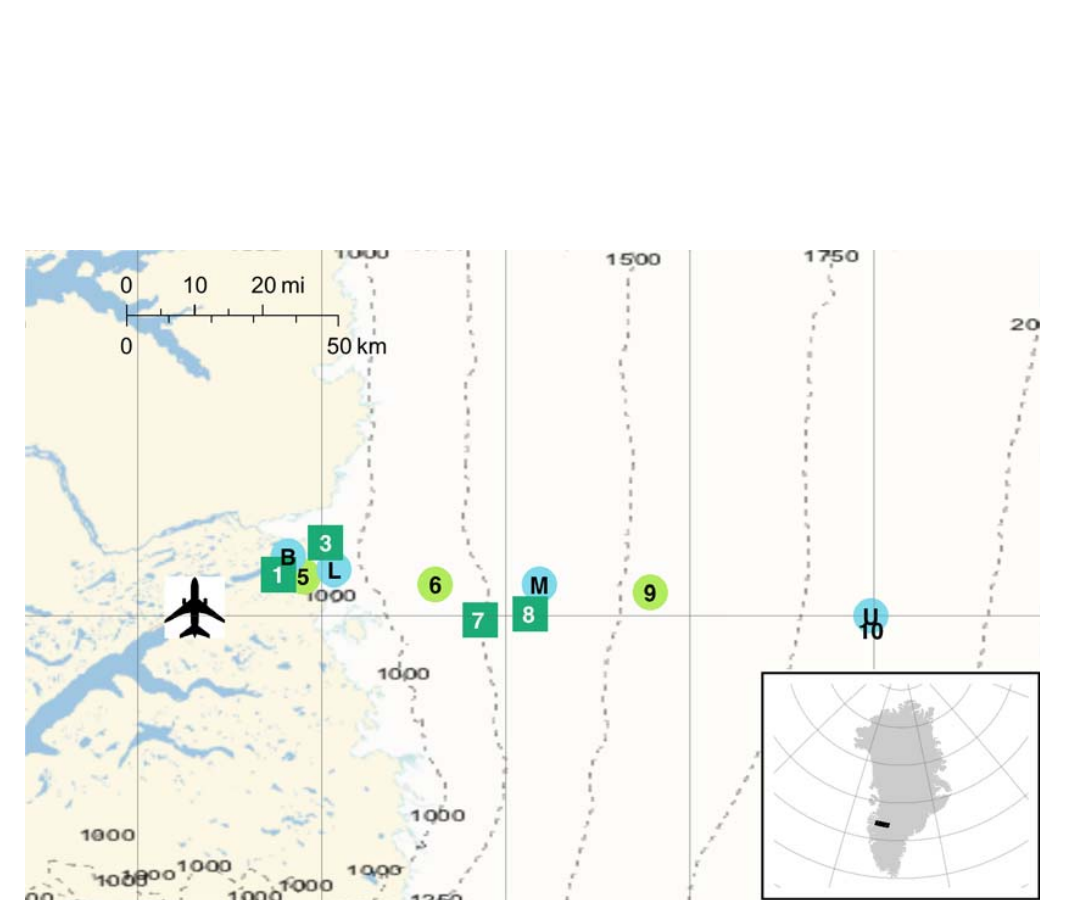

\section{Black carbon and dust accumulation \\ T. Goelles and \\ C. E. Bøggild}

\section{Title Page}

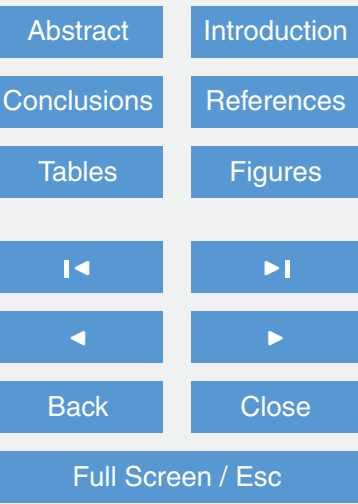

Printer-friendly Version

Figure 4. Weather stations and sampling sites at the K-transect on western Greenland. The airplane symbol marks the Kangerlussuaq airport. Blue circles mark the PROMICE automatic weather stations operated by GEUS and the green circles mark the ones operated by IMAU. The squares mark additional mass balance sites where ice samples have been taken (Wientjes et al., 2012). Station 9 is located near the equilibrium line and sites 6, 7, 8 and $M$ are located in the dark region with lower albedos. 

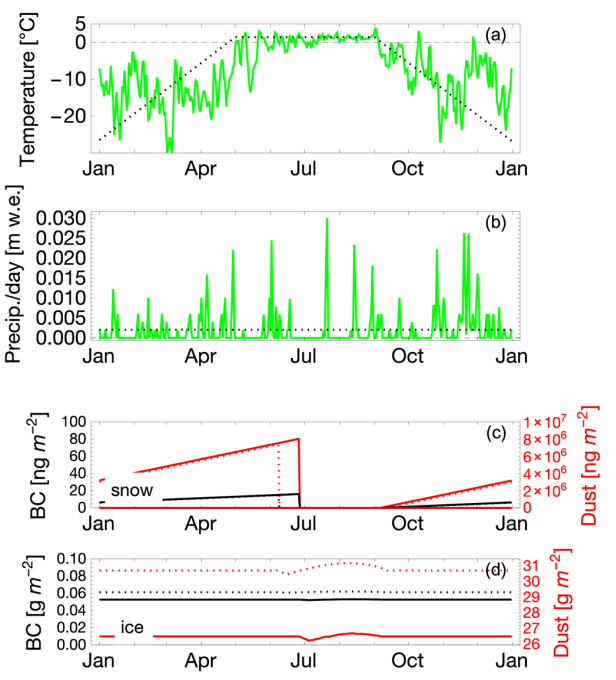

Figure 5. Detailed result of KAN_M station in 2010 with a simulation after spin-up using precipitation from MAR and temperature from the weather station, shown in green and with temperature and precipitation parameterisation (dotted black). Temperature in (a), daily precipitation in (b). Evolution of dust (red) and BC (black) amount in the snow pack and on the ice surface are shown in (c, d). The snow depth evolution in (e) together with the surface type (f) and aerosol content determine the surface albedo evolution in (g).

\section{TCD}

$9,1345-1381,2015$

Black carbon and dust accumulation

T. Goelles and

C. E. Bøggild

\section{Title Page}

Abstract

Introduction

Conclusions

References

Tables

Figures

14

4

Back

Close

Full Screen / Esc

Printer-friendly Version

Interactive Discussion 

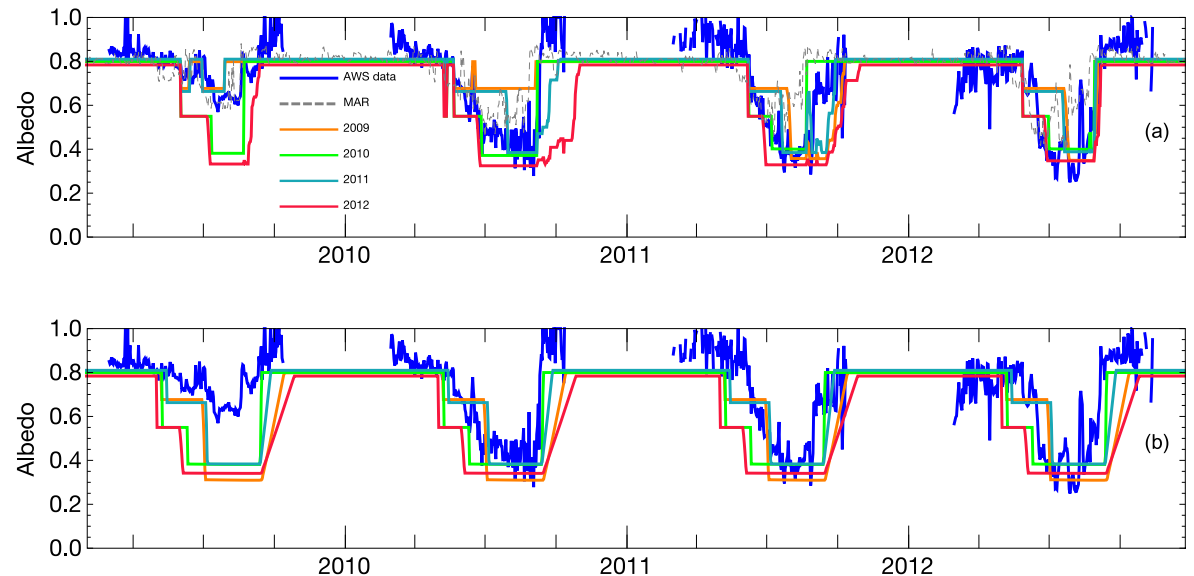

9, 1345-1381, 2015

Black carbon and dust accumulation

T. Goelles and

C. E. Bøggild

Title Page

Abstract

Introduction

Conclusions

References
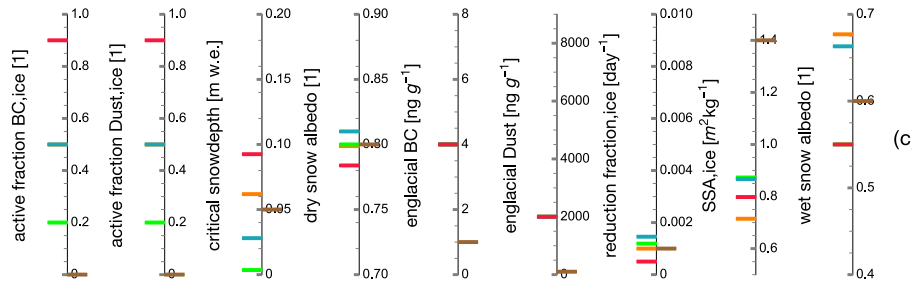

Tables

Figures

14

4

Back

Close

Full Screen / Esc

Figure 6. Albedo evolution of the KAN_M station over the years 2009 until the end of 2012 . Panels $(\mathbf{a}, \mathbf{b})$ show AWS data in blue and different simulations. The parameters are optimised for different yeas and then used to simulate the entire period. In (a) the precipitation comes from MAR model output and the temperature from AWS data and in (b) those are parameterised. Panel (c) shows the range of settings for each year and for Station S5 in brown on the right side of the scales.

Interactive Discussion 

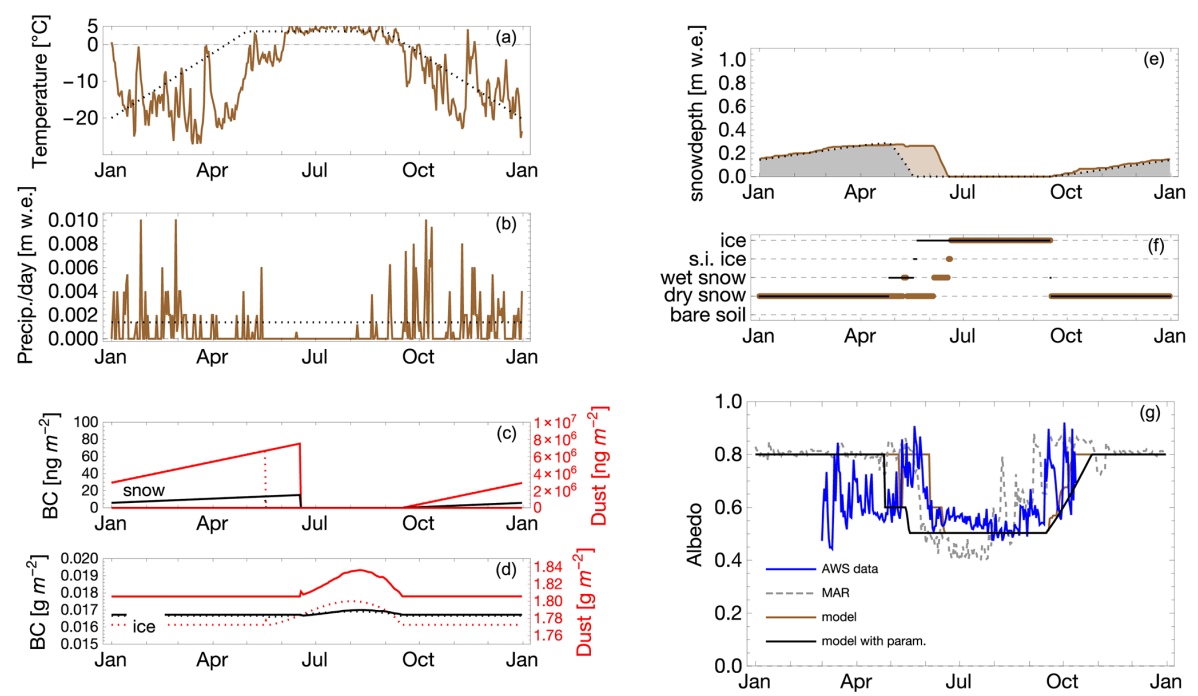

Figure 7. Details of station S5 in the year 2011 with the same plot arrangement as in Fig. 5.
TCD

$9,1345-1381,2015$

Black carbon and dust accumulation

T. Goelles and

C. E. Bøggild

Title Page

Abstract

Introduction

Conclusions

References

Tables

Figures

14

DI

4

Back

Close

\section{Full Screen / Esc}

Printer-friendly Version

Interactive Discussion 